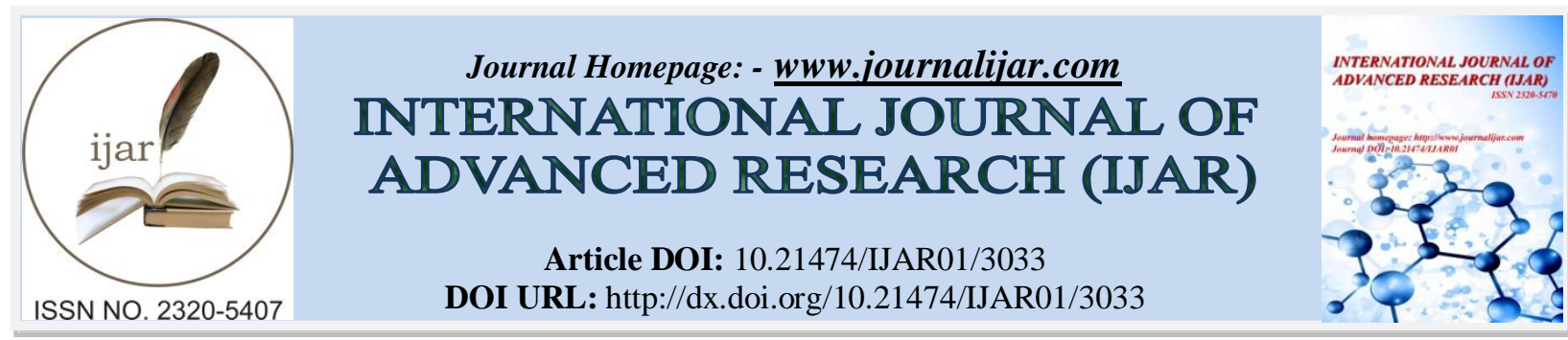

RESEARCH ARTICLE

\title{
A STUDY ON CUSTOMER PERCEPTION TOWARDS ONLINE SHOPPING, SALEM.
}

\section{Dr. M. Dhanalakshmi, M.B.A., M.B.M., M.Phil., Ph.D ${ }^{1}$, Mr. M. Sakthivel, M.B.A., M. Phil., (Ph.D $)^{2}$ and} Mrs. M. Nandhini, M.Com., M. Phil., (Ph.D) ${ }^{3}$.

1. Associate professor, K.S.R College of Arts and Science (Autonomous), Tiruchengode, Tamil Nadu, India 637215.

2. Research Scholar [Ph.D Management], K.S.R College of Arts and Science (Autonomous), Tiruchengode, Tamil Nadu, India - 637215.

3. Research Scholar [Ph.D Commerce], K.S.R College of Arts and Science (Autonomous), Tiruchengode, Tamil Nadu, India - 637215 .

\section{Manuscript Info}

Manuscript History

Received: 30 November 2016

Final Accepted: 28 December 2016

Published: January 2017

Key words:-

Customer Perception, online shopping, Consumer behavior, Websites, Salem.

\begin{abstract}
The present article is an attempt that has been made to study the customer perception towards online shopping at Salem district. In this study an attempt has been made customer perception on online shoppers has been playing a vital role in these scenarios day to day activities in the mind of customers. Customer perception is typically affected in the way of broadly such as advertising, reviews, public relations, social media and personal experiences etc.,. Today we say that customers are mind blowing while go for an online shopping because the wide range of internet facilities in the era. The questionnaire was prepared through the inputs taken from the past researches and also from the feedback of the pilot study. Thus the validated final questionnaire was used to collect data from 150 respondents. The researchers have adopted random convenient sampling technique to gather the data. The data are analyzed using the simple percentage analysis and ANOVA (analysis of variances) methods. The result of this study reveals that customers are intake in the future online shopping in the way of intention for getting a products through internet websites such as EBay, Flipkart etc.,. The study suggested that the advertisers need to focus on their every customer's effort to ticket the market assuming that the influence of the television ads in the online shopping behavior.
\end{abstract}

Copy Right, IJAR, 2016,. All rights reserved.

\section{Introduction:-}

Customer's perception equities are built over a period of moment in time by hi-tech innovations, consistent high quality, hostile advertisement and encouragement and accessibility of the products is another influential success factor, as commodities are of small value, frequently purchased daily use items. So, there is always a chance of customer's discernment switching due to whim buying. (Prerna Kumar 2013) author pointed that the Organisations have long used the traditional media like television, cinema, radio and newspapers for promotional purposes of online shoppers in the mind of customers. Advertisements have been ongoing in various forms such as print, radio, outdoor are prefer to influence the online or internet shopping. 


\section{Objectives of the Study:- \\ Primary Objective:-}

* The primary objective is to the study perception of customers towards online shopping.

Secondary Objective:-

* To determine consumer behaviour in online environment

* To identify the main influencers in online buying process

* To identify people's attitude towards benefits and risks of online shopping

* To find out the preferences of the consumer regarding the attributes of online shopping website.

\section{Materials and Methods:-}

A straight survey was used to collect the data for this study. It was administered to random shoppers at local respondents and to students at Salem district in the interior town. The survey questions were compiled from previous study questions pertaining to the electronic trade shopping behaviors [1, 2, 3, 4, 5, 6, 7, 11, and 12]. These questions were premeditated to gather data on the subjects' perceptions toward online shopping, especially their enthusiasm to perceived online. To validate the clarity of these questions, four professors and nine researchers were asked to read through the survey questions. Revisions to the survey were made based on the feedback received. The survey consists of 52 questions. Besides 7 questions on demographics, the remaining 17 questions were designed to examine subjects' customer perceptions on online shoppers.

The questions has been collected randomly from different region in the Salem district both interior town and exterior region. The questionnaire has been collected 210 and out of 210 One hundred and fifty (150) individuals provided responses to the survey. However, sixty of the responses were not completed, and thus were excluded from the result. Details on the subjects' demographics are provided in Table 1 and 2 below (Results and Discussion).

\section{Results and Discussion:-}

Table 1:- Subject's Demographics.

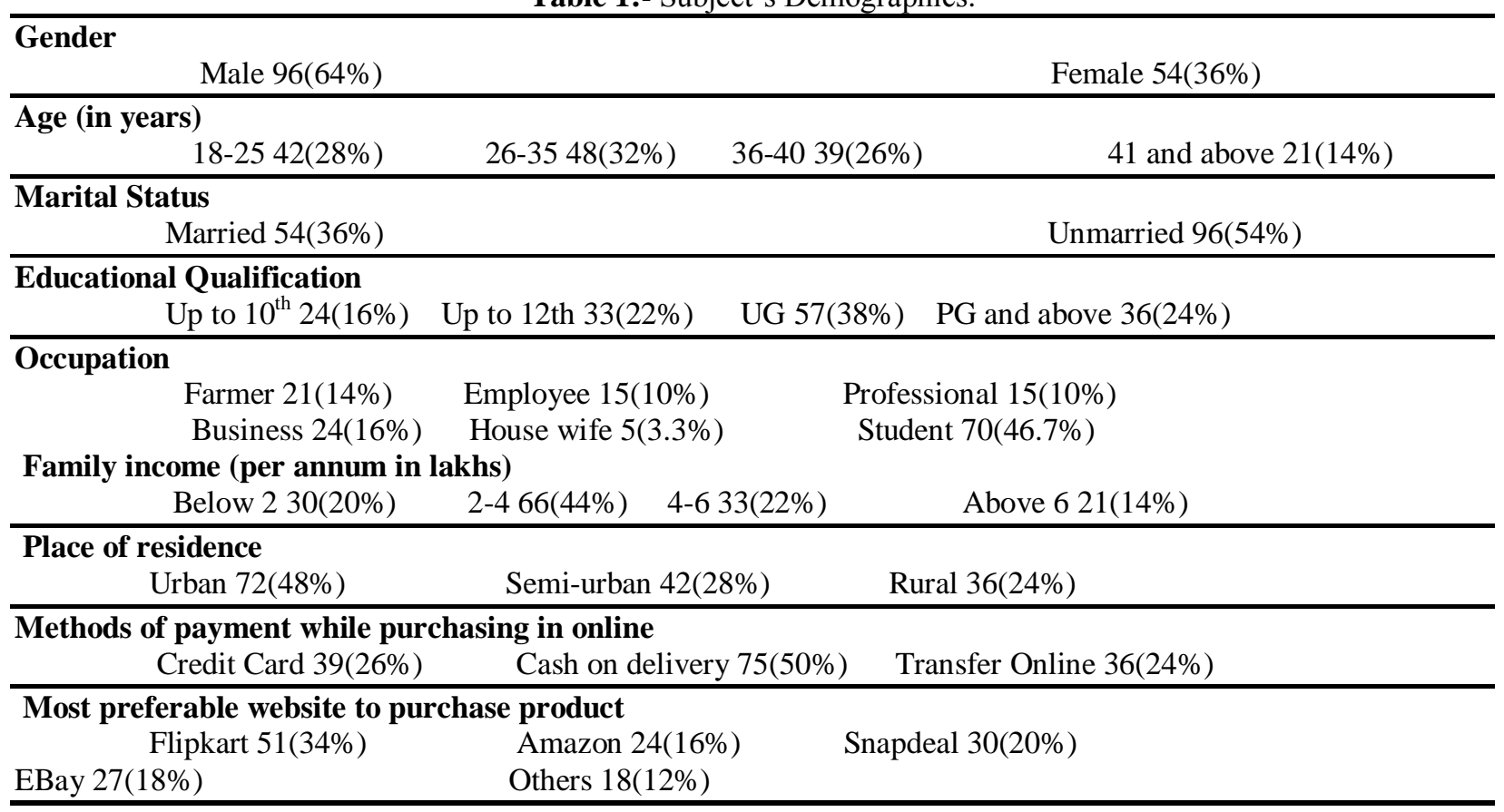

\section{Interpretation:-}

It was the evident table 1 shows that the genders of the respondents on male (64\%) of the online shoppers are perceived day to day activities, 26-35 age groups of the respondents (32\%) are mostly preferred online shopping's in the Salem district in both interior and exterior region, most of the respondents are unmarried (54\%) are preferred online shoppers because of the time constraints in the tight busy schedule, most of the respondents under graduate (38\%) are preferred used to go with online shopping for getting the products at easily, majorities of the respondents 
are Student (46.7\%) are go with online shopping because the internet is in his/her hand at any time to know the detail of the products, Mode of payment while purchasing in online Cash on delivery (50\%) because some of the respondents are not trust the payment mode through internet, so especially in India most of the customers are used to preferred to go with cash on delivery, Most preferable website to purchase product for Flipkart (34\%) are the majorities' perceived online shoppers and remaining are not much perceived from online shopping .

Table 2:- ANOVA

In this table 2 we concluded that the [two groups] age ( $3^{\text {rd }}$ question) and most preferable website to purchase product ( $13^{\text {th }}$ question).

NULL HYPOTHESIS (H0)

There is no significant difference between age and most preferable website to purchase product.

\begin{tabular}{|l|l|l|l|l|l|}
\hline & Sum of Squares & Df & Mean Square & F & Sig. \\
\hline Between Groups & 54.204 & 3 & 18.068 & 26.207 & .000 \\
\hline Within Groups & 100.656 & 146 & .689 & & \\
\hline Total & 154.860 & 149 & & & \\
\hline
\end{tabular}

\section{Interpretation:-}

From the above table, it was identified that the calculated value $(0.00)$ is less than the table value $(0.05)$. Hence, the null hypothesis was rejected and was concluded that there is significant difference between age and most preferable website to purchase product.

\section{Conclusion:-}

The consumer's perception on online shopping varies from person to another and the perception is limited to a certain extent with the availability of the proper connectivity and the exposure to the online shopping has to be improved to make the customer satisfied. The perception of the consumer also has similarities and difference based on their personal characteristics usage based on their needs and demand. The study reveals that mostly the students are attached to the online shopping and hence the elder people don't use online shopping much as compared to the younger ones, so awareness has been fashioned in the coming era. Finally we are suggested that the online transaction should be flexible for the customers who perceived in shopping.

\section{Reference:-}

1. Dolatabadi, H. R., \& Poursaeedi, A. (2012). An Analysis of Factors Affecting onOnline Shopping Behavior of Consumers. International Journal of Marketing Studies , 4 (5), 81-98.

2. Kannaiah, D. (2015). Consumers' Perception on Online Shopping. Journal of Marketing and Consumer Research , 13, 14-20.

3. Khitoliya, P. (2014). Customers Attitude and Perception Towards Online Shopping. Indian journal of research , 3 (6), 18-21.

4. Krishnamurthy. (2015). Customer perception and response towards online marketingin chennai city. Asia Pacific Journal of Research, 1 (XXVII), 44-56.

5. Kumar, P. (2013). A Study on Customer Perceptions towards Online Promotions. IRC'S international journal of multidisciplinary research in social \& management sciences , 1 (3), 116-124.

6. Ling, G. H. (2012). Factors influencing consumers' attitude towards e-commercepurchases through online shopping. International Journal of Humanities and Social Science , 2 (4), 223-230.

7. Puranik, R., \& Bansal, A. (2014). A Study of Internet Users' Perception towards E-shopping. Pacific Business Review International , 6 (9), 37-44.

8. Sapna. ( 2016). Customer Perception Towards Online Shopping. International Research Journal of Commerce and Law , 3 (2), 17-22.

9. Shukla, R. (2016). Gender effect on customers' perceptiontowards online shopping. BVIMSR's Journal of Management Research , 8 (1), 25-30. 